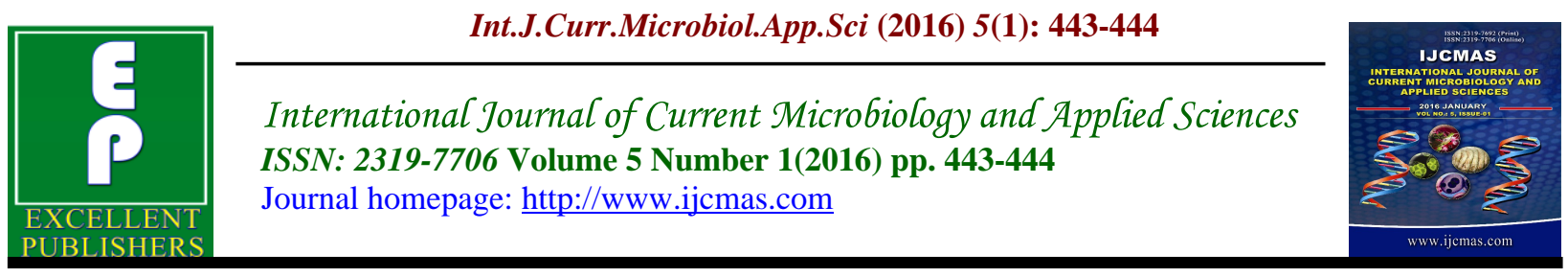

Original Research Article

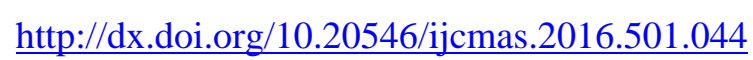

\title{
Photoperiodic effects on histochemical and biochemical variations of Ovotesticular Proteins in the Slug, Semperula maculata
}

\author{
D.L.Bharamal* \\ P.G. Department of Zoology, S.P.K. Mahavidyalaya, Sawantwadi-41510, India \\ *Corresponding author
}

\section{A B S T R A C T}

Keywords

Photoperiod, Ovotestis, Proteins, Slug

Article Info

Accepted:

18 December 2015

Available Online:

10 January 2016
The present investigation was aimed to know the influence of short day (16 $\mathrm{D}: 8 \mathrm{hL})$ and long day $(16 \mathrm{hl}: 8 \mathrm{hD})$ photoperiods on ovotesticular proteins in the stylommatophoran hermaphrodite garden slug, Semperula maculate. It has been observed that the ovotesticular proteins were increased during short day photoperiod when there was active gametogenesis and they were lowered after long day ohotoperiod when there was a suppression in the gametogenesis. The study revealed the relationship between photoperiod and variations in the protein concentrations during gametogenesis.

\section{Introduction}

The period of one day consists of alternating illuminated and dark phases and this recurring rhythms forms the photoperiod. Normally the lighted period is known as photoperiod and relatively lightless period is the scotophase. In many animals now it has been well established that these phases influence the reproductive activities. (Bohlken \& Joosse, 1982; Breed \& Clarke, 1970). But the literature on photoperiod and its effects on invertebrate reproduction seems to be very scanty especially in molluscan. There is no account of influence of photoperiod on the ovotesticular proteins in the pest slug, Semperula maculata. Therefore the present investigation was undertaken.

\section{Materials and Methods}

The slugs were collected during their breeding season from the agricultural fields near Kolhapur, Maharashtra, India. They were acclimated for seven days. After acclimation healthy animals were divided into three groups and exposed first group to control (12hD : 12hL), second to short day $(16 \mathrm{hD}: 8 \mathrm{hL})$ and third group to long day (16hL : 8hD) photoperiods. For light these groups treated with artificial light by 100 watts tungsten filament bulb overhanged the troughs and for dark, troughs were kept in the dark. The experiment was carried out for five weeks. After every week, 2-3 slugs were dissected, their ovotestis was removed and processed for Mercury-Bromophenol blue technique (Mazia et al., 1953) and for 
biochemical protein estimation (Lowry et al., 1951).

\section{Results and Discussion}

The histological and histochemical observations are recorded in Table 1, showed with visually estimate intensity and shade with four plus (++++), representing the strongest activity. Histologically some interesting alterations were observed in ovotesticular cell types in germinal epithelial cells, sertoli cells, nurse cells, sperms and ova. Staining intensity and the size of the cell types were increased in short day whereas they were reduced in long day pohotoperiods. Histochemical observations showed all the cell types were full of proteins but they were maximum in short day and minimum in long day photoperiod. Biochemical results are recorded in Table 2 indicated increase in ovotesticular proteins in short day and it decreased in long day photoperiods.

Our results were coincided with as that of observed in Lymnaea stagnalis in which there was an increase in nuclear proteins during previtellogenesis (Bolognari and Frascesco, 1963), maximal protein levels gravid gonads in Katherina tunicata (Giese and Hart, 1967) and maximum protein concentration during the period of gametogenesis and gamete maturation (Nanaware, 1974).

The present study conclude that during short day photoperiod the gametes were matured and full of proteins whereas the proteins were at minimal levels when sperms and ova were not actively produced or they were immature due to long day photoperiod.

\section{References}

Bohlken, S.\& Joosse, J. 1982. The effect of photoperiod on female reproductive activity and growth of the ulmonate snail LKymnaea stagnalis kept under laboratory conditions. Int.J.Invert Reprod. 4:213-222.

Bolognari,A.\& Francesco, C. 1963. Structural and cytochemical examination of the nuclear apparatus in the oocytes during the growth of Lymnaea stagnalis.

L.ATTI.Soc.Pelorifana, Sci.Fis.Mat.Nature. 9:273-286

Breed, W.G. \& Clarke, J.R.1970. Effect of photoperiod on ovarian function in the vole, Microtus agrestis J.Reprod.Fert. $23: 189-192$.

Giese, A. \& Hart, M. 1967. Seasonal changes I component indices and chemical composition in Katherina tunicate J.Exp.Mar.Biol.Ecol. 1:34-46.

Lowry, O., Rosenbrough, N., Farr, A. \& Randall, R. 1951. Protien measurement with the Folin Phenol reagent. J.Nop;.Chem. $193: 265-275$.

Mazia, D., Brewer, P. \& Alfert, M. 1953. The cyochemical staining and measurement of protein with bromophenol blue. Biol. Bull. 104:5767.

Nanaware, S.G.1974. Biochemical and histochemical studies on the reproductive organs of some gasdtropods. Ph.D.Thesis. Shivaji University, Kolhapur. India.

\section{How to cite this article:}

Bharamal, D.L., 2016. Photoperiodic effects on histochemical and biochemical variations of Ovotesticular Proteins in the Slug, Semperula maculate. Int.J.Curr.Microbiol.App.Sci. 5(1): 443-

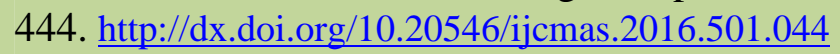

